\title{
Binary Representations: British Press Reporting of the Muslim/Asian Other Outside the Context of Terrorism (1989-2007)
}

\author{
DR. MATT ATKINSON, University of Liverpool
}

\begin{abstract}
This paper explores the ways in which the coverage of the Muslim Other has changed over time outside the specific context of 'Islamic' terrorism. Three case-studies are examined: the Satanic Verses incident of 1989, the Bradford Riots of 2001, and the Gillian Gibbons incident of 2007. The analysis indicates that the British press tends to conflate British Asians and British Muslims, although this was mainly evidenced in the 2001 Bradford Riots sample. However, comparing the coverage of the 2007 Gillian Gibbons incident to that of the 1989 Satanic Verses, suggests that the representation of Muslims may have become more positive between 1989 and 2007. Although this finding may appear to be counter-intuitive given that this period included events such as $9 / 11$ and 7/7, which are generally regarded as having worsened negative stereotypes of Muslims, this data is in keeping with existing studies, such as Featherstone et al. (2010), who argue that during this period the British press struggled to reconcile the need to 'represent Britain as a unified multicultural imagined community' with "'othering" the bombers as Islamic radicals who were nonetheless normal British citizens' (179). This has led to a duality in coverage of Muslims in the British press, where Muslims can be either 'good' or 'bad', but nothing in between.
\end{abstract}

\section{KEYWORDS}

British; Muslim; South Asian; Press; Terrorism; Wordsmith; Corpus

\section{Introduction}

This article explores the coverage of British Muslims and British South Asians outside the context of terrorism. The rationale for this study is explained by the fact, widely discussed in the literature, that British-born Muslims began to be categorised as 'Islamic terrorists' after 9/11 (Featherstone et al. 2010, 176). For example, Moore et al. (2008) point out that 36 percent of all news stories in the British press which involve British Muslims also involve terrorism (3). Research conducted prior to 9/11, however, indicated that British Muslims tended to be excluded from such category, unlike Muslims born elsewhere (Featherstone et al. 2010, 176). Furthermore, the London bombings of 7 July 2005 were perpetrated by Muslim, British citizens, meaning that this trend is likely to have become even more pronounced. Studying media coverage of events related to 'Islamic' terrorism such as 9/11 or $7 / 7$ is productive in many ways, although it is likely to contain representations of Muslims as terrorists because people claiming to be Muslim committed these atrocities. Consequently, focusing on those specific events may pre-determine the research findings. In order to analyse the way in which the majority of Muslims are usually reported by the media, it makes sense to examine the coverage of events which did not involve terrorism. 
Accordingly, this study focuses on the following events: the Satanic Verses incident of 1989, the Bradford 'Race' Riots of 2001, and the Gillian Gibbons incident of 2007. Whilst two of these events involved a potential threat to the life of a specific person (Salman Rushdie in the case of the Satanic Verses event, and Gillian Gibbons in the 2007 incident), neither of them involved 'terrorism' as such. In each case, threats of violence were made against a British individual by Islamic agents. In the case of the Satanic Verses, Iran's spiritual leader Ayatollah Ruhollah Khomeini (Elgamri 2010) was offended by the actions of the character Mahound in Rushdie's novel The Satanic Verses (1988), a character generally considered to be an allegory of Prophet Mohammed (Brians 2004). In the Gillian Gibbons incident, the government or, rather, the legal establishment of Sudan, threatened schoolteacher Gillian Gibbons for allowing the children under her supervision to name a teddy bear Mohammed. This was, again, perceived as an insult to Prophet Mohammed.

The remaining event, the Bradford 'Race' Riots, is different from the previous ones in that it did not exclusively involve religion. As with other riots, this event was motivated by a number of different factors. Bradford's population includes a high percentage of Muslims and South Asians ${ }^{1}$ (Peach 2005), and it is generally agreed that a good deal of the rioting which took place there in July 2001 was perpetrated by young people of a South Asian ethnicity (Amin 2003; Kundnani 2001). Muslims and South Asians (a religious and an ethnic category, respectively) are commonly linked in British conceptualisations of either descriptor. Poynting and Mason, for instance, describe the way in which

the figure of the so-called "Paki" has been a key object of racial hatred for several generations, and this "colours" contemporary, post-9/11 Islamophobia in a country [the UK] where most Muslims, and the most recognizable Muslims, are of South Asian ancestry $(2007,63)$.

The conflation between South Asian identity and Muslim identity is not only inaccurate, but it is also problematic in that it misrepresents those who are either South Asian but not Muslim, or Muslim but not South Asian. Peach (2005) has carried out extensive work based on the 2001 UK census, the first one to include a question on religion. Given that no comparable data exists regarding religion from before 2001, Peach uses back projection to extrapolate the religious composition of the South Asian population in the UK as far back as 1951. Whilst he acknowledges that this extrapolated data is 'very approximate' (Peach 2005, 23 ), it is clear that the data shows a trend of growing diversity in terms of religion among the UK's South Asian population (24). The census of England and Wales conducted in 2011 shows that both the South Asian and Muslim demographics have grown at a large rate since 2001 (BBC 2012a; BBC 2012b). This suggests that any direct identification between these groups is becoming increasingly inaccurate.

This is further complicated by the fact that terms such as 'race' and 'ethnicity' tend to be poorly understood. This is also acknowledged by the Oxford English Dictionary, which mentions that the term 'race' is 'often used imprecisely' (Hawkins and Allen 1991, 1188). In this respect, Jakubowicz et al. (1994) question whether race stands for 'skin colour, or geographical place of birth, or nationality, or culture, or something else -some essential psychic or moral quality that can be differentiated' (28). For the purposes of this paper, South

1 Here, the term 'South Asian' refers to anyone of an Indian, Pakistani or Bangladeshi identity. Although these three identities do not represent every possible South Asian identity, they are the three most predominant ones in the UK (Peach 2005). 
Asian identity will be considered to be 'racial', whilst a Muslim identity will be considered to be religious. Because of the importance assigned to race in popular conceptions of British Muslims, the case of the Bradford Riots was included in this study as one of the rare examples of a major British news story which directly involved British South Asian people. Whilst the riots seem to have had a compound 'cause', often seen to be a process by which citizens had been divided up by neighbourhood, class, and/or race in the city, this does not generally include religion. Kundnani (2001), for instance, describes the violence which took place in $2001^{2}$ as 'the violence of communities fragmented by colour lines, class lines and police lines [...] the violence of hopelessness [...] the violence of the violated' (105). Also referring to the 2001 riots, Rex states that:

The discussion following the Northern riots made little mention of Islam as an exacerbating factor. Nor did the young white rioters often mention Islam as the basis of their hostility. They simply saw Asians as taking resources away from themselves and leaving them to live in poverty. Muslim leaders on the whole played a moderating role $(2005,237-238)$.

The Ouseley Report (2001) on community relations in Bradford does mention religion as a key aspect in the city, but it could not relate this to the riots given the timing of the report's publication during the violence. ${ }^{3}$ It states that 'the key concern in the District is that relationships between different cultural communities should be improving, but instead they are deteriorating. There are signs that communities are fragmenting along racial, cultural and faith lines' (6). The event that ignited the Bradford Riots appears to have been a planned rally by the far-right National Front (NF) on 7 July 2001. Although this event was banned by the Police, a number of NF supporters were turned away from a Bradford train station on that day (Mail on Sunday 2001). A counter-demonstration by the Anti-Nazi League (ANL) became violent when crowds either 'discovered' (BBC 2008) or heard 'the rumour' (Herbert 2001) that a number of white racists had gathered at a nearby pub. The ANL rally consisted largely of 'Asian' people (Moss 2001) and, although small skirmishes developed between Asians and whites, a much larger crowd of Asians was reported to have embarked on a rampage in the city centre, and later in the (largely Asian) Manningham district (Ward 2001).

Considering that the riots do not appear to have been directly motivated by religion, any mention of religious descriptors by the press might involve a conflation between religion and race. Therefore, the Bradford Riots represents a useful case study in the context of the research conducted here. This event was selected over other similar instances of violence which occurred across the north of England in 2001 (such as those which took place in Burnley and Oldham) for two reasons: first, the Bradford Riots occurred after the violence in Burnley and Oldham took place, meaning that the press had had time to find a way to frame these events; secondly, the Bradford Riots were more significant in terms of their time span and the destruction they caused, subsequently increasing its news value. One interesting feature of the 2001 riots is that they happened just before the events of 9/11 so, all in all, the corpus analysed in this study can be understood as a snapshot of the news coverage of British South Asians and, as explained above, British Muslims, just before 9/11 took place.

\footnotetext{
2 Kundnani (2001) refers here to the violence which developed across the north of England in 2001, rather than Bradford in particular.

3 The report was published on 12 July 2001, and reportedly it had been completed 'months before' the violence in Bradford took place (Guardian 2001).
} 


\section{Methodology}

Considering the selection of case studies for this project, news articles were sampled for seven days in 1989 (from 15 February 1989, one day after the fatwa against Salman Rushdie was announced, until 21 February 1989), 2001 (from 8 July 2001, one day after the Bradford Riots began, until 14 July 2001), and 2007 (from 28 November 2007, the day when Gillian Gibbons was charged with an offence, until 4 December 2007). The articles for the first case study were collected manually from the British Library Archive, while the sample for the remaining two events was searched through the online newspaper database Lexis Library. Sampled newspapers included the Daily Express, the Daily Mail, the Daily Mirror, the Daily Star, the Daily Telegraph, the Guardian, the Independent, the Sun and The Times, as well as their Sunday editions (Sunday Express, Mail on Sunday, Sunday Mirror, The People, Sunday Telegraph, Observer, News of the World, and Sunday Times). After the initial search was completed, irrelevant results were deleted from the sample, which eventually consisted of 600 news articles, with the following distribution:

\begin{tabular}{|l|l|l|l|l|}
\hline & $\begin{array}{l}\text { The Satanic } \\
\text { Verses incident } \\
(1989)\end{array}$ & $\begin{array}{l}\text { The } \\
\text { 'Race' Bradford } \\
(2001)\end{array}$ & $\begin{array}{l}\text { The Riots } \\
\text { Gibbons incident } \\
(2007)\end{array}$ & TOTAL \\
\hline $\begin{array}{l}\text { Number of } \\
\text { Articles }\end{array}$ & 252 & 156 & 192 & 600 \\
\hline $\begin{array}{l}\text { Total Corpus } \\
\text { Length (Words) }\end{array}$ & 123,199 & 72,290 & 76,096 & 271,585 \\
\hline
\end{tabular}

Table 1: Distribution of articles

The final sample was collated into a database and an initial quantitative analysis was conducted using the software package Wordsmith Tools 5, which generates lists with the frequency of terms, produces collocation ${ }^{4}$ analyses for separate terms, and creates lists of words and phrases which appear to be statistically significant within a corpus. The data obtained from this analysis was then used to carry out a qualitative analysis. The combination of both approaches provides a more comprehensive understanding of the sample, while also making the analysis manageable. Considering the size of the sample, a corpus-driven method, such as the one described by Baker (2006), enabled a thorough, accurate and replicable study. Corpus analysis, however, also presents some challenges:

We need to bear in mind that, because corpus data does not interpret itself, it is up to the researcher to make sense of the patterns of language which are found within a corpus, postulating reasons for their existence or looking for further evidence to support hypotheses. Our findings are interpretations, which is why we can only talk about restricting bias, not removing it completely (Baker 2006, 18, original emphasis).

It is also important to remember that a corpus-driven approach will often miss many of the subtleties and inferences which can be drawn out by a more qualitative method, such as the one employed by Richardson (2004) to analyse similar texts to those analysed here.

4 'Collocation' refers to those words which tend to appear together. Wordsmith Tools allows for various levels of analysis, for example, within two words or within five words to the left or to the right of a given term. 
Richardson suggests that future researchers in this area would be wise to adopt a 'contextsensitive analytic position' (232) similar to his own, and states that this would:

not only foreground broadsheet newspapers' location in the social and political world, but should also illustrate the way journalists are marshalled by capitalism, manipulated by powerful social/political elites and the manner in which journalism is used to maintain racist global inequalities (Richardson 2004, 233, original emphasis).

Corpus analysis also ignores many non-textual factors which play a role in deciding how a newspaper article will be interpreted by the reader. Mautner (2009) mentions aspects such as 'typography, colour and text-image relationship' (129) as being important in this respect. Although this study does not focus on these factors, it is certainly concerned with the context within which the sampled articles were published. In order to bridge the gap between purely quantitative corpus-driven analysis and qualitative analysis, the features of Wordsmith Tools were used to reveal clusters of words which occurred frequently within the sample. These clusters could then be analysed in more detail, providing further insight into how, and perhaps why, they had been used. For example, a collocation analysis for the words 'Muslim', 'Moslem' (an alternate spelling) and similar words (such as plurals) within the Satanic Verses corpus revealed that the phrases 'Muslims in Britain' and 'Moslems in Britain' were two of the most common clusters of words relating to these particular terms. This quantitative data was then used to produce a list of all the articles which contained these phrases in order to analyse them in further detail (in this case, 24 articles were examined qualitatively).

\section{Findings}

In order to conduct a comparative analysis between the three case studies, four indicators were used to represent various aspects of the coverage of British Muslims and South Asians: 'Conflation', 'Othering', 'Voice' and 'Change over time'. The first indicator, 'Conflation', relates, as discussed above, to the conflation of popular stereotypes often experienced by Muslims and South Asians in the British context. The next indicator, 'Othering', is related to the first one, and refers to the process by which a group of people is stereotyped by another group of people. These stereotypes are applied to real people without considering their heterogeneity of any social group. Said (1978) points out the ways in which people of the 'Occident' have imagined people from the 'Orient' throughout history when large distances separate these groups. In this respect, van Dijk (2000) explains the power of the media in the establishment of what he terms 'ethnic affairs', which includes the fact that most white people, not having an opportunity to engage with minorities frequently, tend to gain their knowledge about these social groups only from the media (36).

The fact that media coverage of Islam tends to represent this religion and its followers as one homogenous group is well documented (Poole 2002; Said 1981). Richardson (2004) points out that, in British broadsheets, 'actors are divided into "British" and "nonBritish/immigrant", with (often British) Muslims being included within the second of these categories' (113, original emphasis). This observation emphasises the fact that the process of Othering not only takes place across long distances, but also within geographical borders. Richardson further states that the Muslims" 'lack of "Britishness" divides "Them" from "Us", (113). 
Considering that neither British Muslims nor South Asians represent dominant groups in Britain, the third indicator, 'Voice', is concerned with the extent to which these groups are 'heard' through the press. The way in which the voices of 'ordinary' British Muslims and South Asians are represented is an essential part of this study, since it is indicative of how they are allowed to articulate their views in the media and the extent to which this is compatible with the held stereotypes of these groups. As Fowler (1991) puts it, a stereotype represents 'a socially-constructed mental pigeon-hole into which events and individuals can be sorted, thereby making such events and individuals comprehensible' (17). For the audience to make sense of these representations, these must be similar to existing ones, which in turn serves to perpetuate the process of Othering.

The fourth and final indicator, 'Change over time', is a key aspect in this study, as it takes account of the changes that the representation of Muslims has gone through over the years. This indicator also considers the extent to which racial stereotypes may have become more or less conflated with religious ones. In this respect, Poynting and Mason (2007) claim that the classification of the Asian Other in the British media may have undergone a transformation from 'Asian' or 'Pakistani' to 'Muslim' (81). Law (2010) also describes how hostilities against the Other were not always limited to Muslims themselves, but those who looked as if they might be 'of Muslim or Arab descent' also became targets of those aggressions (148). On a similar note, Sardar (2002) notes how the first victims of 'revenge attacks' in New York after 9/11 were, in fact, Sikh (51). In the British context, Frost (2008) also points out that, while the total number of offences motivated by religion between 2004 and 2005 dropped from 49 to 34, in 23 of these cases the 'actual or perceived religion of the victim was Muslim' (Frost 2008, 567). Although not all of this data is directly related to representations as such, they are all indicative of the conflation between the Muslim and the South Asian Other and how this may vary at different points in time.

The analysis shows that newspaper reporters relied, across all three case studies, on British Muslim leaders when the British Muslim community was included in the news articles. While journalists tend to approach only the head of an organisation to represent its standpoint, due to their tight deadlines, this strategy may serve to strengthen the perception that the Other is a homogenous group in which all members share the same point of view. Others are very seldom dealt with as 'normal' individuals who can speak for themselves, while Muslim leaders were introduced as the head of a particular organisation without explaining the extent to which they are representative of the wider community.

In contrast, the coverage given to the views of Anglican bishops and archbishops was evidenced in the three samples, although it was most significant in the Satanic Verses case study. Even though members of the Anglican Church are knowledgeable of the subject of blasphemy, it is remarkable that their reading of the event is expressed in articles which are concerned with Islam. This perhaps points to the fact that journalists were not writing for a generally Muslim audience but, nevertheless, it further contributes to the Othering of Muslims: this journalistic practice does not allow for an understanding of Islam that comes from within, but one that is channelled through the views of someone from outside.

These findings must, however, be considered in light of the arguments made by Hall (1990) and Law (2002), who suggest that it is unlikely that the press functions as a consciously prejudiced system. Hall points out that those involved in the production of media do not tend to be actively racist, but it is rather the structure and practices of the media that cause them to 
produce racist content, a process that he calls 'inferential racism' (Hall 1990, 20). This form of racism relies on a set of 'unquestioned assumptions' in order to operate within the industry, which allows 'racist statements to be formulated without ever bringing into awareness the racist predicates on which the statements are grounded' (Hall 1990, 13). In this respect, Law (2002) describes a process, the 'great anti-racist show', through which the press industry attempts to mask this 'inferential racism' while still implementing it. He defines this as

an outward, empty attempt of mere display masking continuing normative and progressive whiteness in news organisations, racial and ethnic inequalities of power and employment and a collective failure to provide appropriate quality news services for black and minority ethnic communities and consumers (76).

Also relevant here is a form of racism which Billig (1991) refers to as 'de-racialised in that the attitudes are justified by traditional values, such as equality and fairness, and not by overt racial themes' (124). This mechanism allows for statements such as the almost cliché 'I'm not prejudiced, but', by which a person qualifies a racist statement by first denying that they are in fact racist (Billig 1991, 125). In these instances, the prejudiced theme may exist at a level which is psychologically lower than the denial of prejudice, so the racial statement is considered to be the genuine attitude while the person making the statement may not believe that they are in fact racist (126).

Another notable finding is that, although there was evidence of the Muslim/Asian Other being covered as a homogenous group, as suggested by Said (1981) and Poole (2002), this was mainly observed in the data sampled for the Satanic Verses incident and the Bradford Riots. Coverage of the Gillian Gibbons case study tended to portray the Other in more complex ways. Leaving the coverage of the Bradford Riots aside for one moment, it is useful to consider the differences between the coverage of the Satanic Verses and Gibbons incidents, given the similarities shared by the events themselves (see above). One of the most significant aspects of the Satanic Verses coverage was the way in which Ayatollah Khomeini was frequently represented. Ayatollah Khomeini was a cleric of the Shia, ${ }^{5}$ which accounts for around 89 percent of Iranian Muslims (Bennett, 2011: 131). On a worldwide scale, however, Sunnis account for between 85 and 93.5 percent of the world's Muslim population (Bennett 2011, 130). These figures are mirrored in Britain, where around 87 percent of all Mosques are Sunni (Peach 2005, 28). The Shia differs from the Sunnis on 'questions of succession, law and authority, interpretation of the Qur'an, marriage, inheritance, and jurisprudence in general' (Elgamri 2010, 103).

Given these differences, it appears that only a minority of the world's Muslim population would be likely to recognise a decree which came from a Shia Muslim cleric, such as Ayatollah Khomeini, as well as the fatwa he declared denouncing Salman Rushdie in 1989. However, the relative significance of Khomeini's position to the majority of the Muslim population worldwide was rarely explained, and his precise religious standpoint was barely discussed. Tables 2 and 3 below indicate that, although certain newspapers -most notably The Independent- included these terms in their sampled articles, some newspapers did not mention them at all.

5 In the English language, 'Shia' is a particularly difficult term to work with in corpus analysis, as it has a number of different spellings ('Shia', 'Shias', 'Shiites' and 'Shiism'). Terms that refer to Sunni Islam include 'Sunni', 'Sunnis' and 'Sunnism'. 


\begin{tabular}{|l|l|l|l|}
\hline & Shia Terms & Sunni Terms & TOTAL \\
\hline Daily Express & 2 & 2 & 4 \\
\hline Daily Mail & 0 & 2 & 2 \\
\hline Daily Mirror & 0 & 0 & 0 \\
\hline Daily Star & 0 & 0 & 0 \\
\hline Daily Telegraph & 1 & 1 & 2 \\
\hline Guardian & 5 & 4 & 9 \\
\hline Independent & 17 & 7 & 24 \\
\hline Sun & 0 & 0 & 0 \\
\hline The Times & 4 & 2 & 6 \\
\hline TOTAL & 29 & 18 & 47 \\
\hline
\end{tabular}

Table 2: Frequency of terms relating to Sunni and Shia Muslims in the Satanic Verses Corpus by Newspaper (Weekday Newspapers)

\begin{tabular}{|l|l|l|l|}
\hline & Shia Terms & Sunni Terms & TOTAL \\
\hline News of the World & 0 & 0 & 0 \\
\hline Mail on Sunday & 0 & 0 & 0 \\
\hline Observer & 7 & 3 & 10 \\
\hline The People & 0 & 0 & 0 \\
\hline Sunday Express & 0 & 0 & 0 \\
\hline Sunday Mirror & 0 & 0 & 0 \\
\hline Sunday Telegraph & 0 & 2 & 2 \\
\hline Sunday Times & 0 & 0 & 0 \\
\hline TOTAL & 7 & 5 & 12 \\
\hline
\end{tabular}

Table 3: Frequency of terms relating to Sunni and Shia Muslims in the Satanic Verses Corpus by Newspaper (Sunday Newspapers)

Although it is possible to discuss the rifts that exist within Islam without using the terms specified above, it seems unlikely that this would happen on any regular basis. The qualitative analysis that followed this quantitative data confirms this observation, at least within the sampled articles. The fact that the corpus included a large number of references to the death threats that were made against Rushdie from within Britain would provide an opportunity for reporters to contextualise the event by explaining that the majority of British Muslims belonged to a different section of Islam. However, this did not happen. Even though Rushdie's novel may be offensive to all Muslims, regardless of their specific beliefs, the overall omission is illustrative of the tendency to treat Islam and its followers as if they constitute one single group.

In the Gillian Gibbons case study, however, Muslims tended to be treated as a more complex group, which suggests that there may have been a shift in the reporting of Islam as an Other between 1989 and 2007, although the limitations of this study does not allow for definite conclusions in this respect. One of the most interesting indications of this shift in the Gillian Gibbons sample was a tendency to use the term 'hardline' to describe Muslims. More specifically, this term appeared 27 times, while the variant 'hard-line' was counted 5 times. Although the term 'hardline' can be used in a number of different ways, the Wordsmith tool showed that every instance was related either to protestors in Sudan (protesting for a harsher sentence for Gibbons), religious leaders in Sudan, or the Sudanese government. This finding is remarkable because the fact that some Muslims are 'hardline' implies that not all Muslims 
share the same perspective, which means that there at least some degree of variation within the group.

Regarding the analysis of the Bradford Riots of 2001, one notable finding is the way in which South Asians and Muslims were conflated as one single identity. This means that terms such as 'Muslims' and 'Asians' are used interchangeably to refer to either group, as discussed above. Consequently, not only are Muslims represented as one homogenous group, bit South Asians are also depicted as such. In this sample, it was British South Asians who were stereotyped as, and presumed to be, Muslim. However, there were no instances of British Muslims being represented as British South Asian by the press. Table 4 below shows the frequency of the term 'Muslim' together with some variants in the Bradford Riots Corpus:

\begin{tabular}{|l|l|}
\hline Term & Number of Instances \\
\hline Muslim & 45 \\
\hline Muslims & 21 \\
\hline Moslem & 12 \\
\hline Moslems & 3 \\
\hline Islam & 2 \\
\hline Islamic & 5 \\
\hline
\end{tabular}

Table 4: Frequency of the term 'Muslim' and related terms in the Bradford Riots Corpus

Further analysis showed that many of these instances were collocated with terms such as 'communities' and 'white'. More specifically, the collocation with 'white' was counted six times, which is of particular interest to this study. The following excerpts are representative of this finding:

As the city's white and Muslim communities become increasingly segregated, living in separate areas and attending different schools, their fear of crime -and of each other- is growing (Baird and Cooke 2001, my emphasis).

Our politicians, public men and pontificators of all kinds are incessantly talking about 'racism'. But when they are confronted with genuine, unmistakable racial hatred, as with the Muslim Pakistani and white English rioters in Bradford, they change their tune (Simple 2001, my emphasis).

These quotes illustrate the fact that conflation between racial and religious identities was indeed present in the press reporting of the 2001 Bradford Riots, as some actors are described as 'white', that is, in racial terms, while the Other is referred to as 'Muslim', that is, in religious terms. In addition, this conflation resembles, on the surface, a process identified by Richardson (2004), whereby the descriptor 'Muslim' is used to 'identify negative social actions and negative social actors' (231). When actors are acting 'lawfully or otherwise legitimately', Richardson states that they are instead labelled as 'Asian' or 'of Middle Eastern descent' (231). However, we must also consider that the Bradford Riots data has shown that, while the term 'Muslim' was certainly present throughout the corpus, racial descriptors such as 'Asian' or 'Pakistani' were much more commonly used to describe rioters. Therefore, Richardson's statement only applies to this case to a limited extent. 


\section{Conclusions}

Given that much of the material sampled in this study suggests that the Muslim and the South Asian Others were being grouped into a homogenous group, it seems unlikely that this practice would have ceased significantly by the time the Gillian Gibbons event took place in 2007. Considering that in the interim period highly mediatised attacks such as $9 / 11$ and $7 / 7$ had been perpetrated by terrorists claiming to be Muslim, it also seems improbable that the coverage of Muslims in general would have improved by becoming less inaccurate and more sensitive to the heterogeneity within Islam. In fact, existing studies have shown that, following the 7/7 attacks, reporting of British Muslims in the British media increasingly represented Muslims as 'Islamic terrorists' (Featherstone et al. 2010, 176). However, Featherstone et al. also state that 'the press has struggled to reconcile the need to represent Britain as a unified multicultural imagined community with Othering the bombers as Islamic radicals who were nonetheless normal British citizens' (179). They further argue that

the British media's response to 7/7 was to bypass the politics of the suicide bombers and, instead, focus on their criminality in an attempt to save some sense of British multiculturalism by repeating the binary form of good Muslim/bad Muslim popularised by Bush/Blair following 9/11 (179-180).

This duality is also identified by Sardar (2002), albeit in the US context. He states that 'the post 9/11 USA recognises only two kinds of Muslims: the terrorist (who has declared war on the West) and the apologetic (who claims to be liberal and defends Islam as a peaceful religion)' (51).

The findings in this study suggest that, since $9 / 11$ and 7/7, Muslims are indeed reported in a dualistic manner by the British press. Therefore, the press reports on 'good Muslims' and 'bad Muslims', but rarely (if ever) does it report on Muslims who are simply 'normal'. The data also indicates that the process of Othering includes a conflation between stereotypes defined by religion and those defined by race. It appears that the stereotype of the Asian Other in the British press tends to be overridden by that of the Muslim Other, as argued by Poynting and Mason (2007). Certain established news practices and mechanisms ensure the perpetuation of this Othering process, which continues to place Muslim and Asian Others outside mainstream society. Whilst the data presented here is only a snapshot of a wider study (Atkinson, 2012) and cannot be used to make definite claims in a broad sense, evidence was found to support these conclusions in relation to the specific case studies analysed in this project, which is in keeping with the arguments of Sardar (2002), Poynting and Mason (2007) and Featherstone et al. (2010).

\section{References}

Amin, A. (2003) 'Unruly Strangers? The 2001 Urban Riots in Britain', International Journal of Urban and Regional Research, 27, 2, 460-463.

Atkinson, M.W. (2012) A Study of the Representation of 'Muslim' and 'Asian' Identities in the British National Press, Unpublished PhD Thesis, University of Liverpool. 
Baird, R. and Cooke, H. (2001) 'As Riots Goes [sic] On, New Report Shows Segregation in Bradford is Only Getting Worse; A Divided City Waking Up Each Day in the Grip of Fear', Daily Express, 11 July, 8.

Baker, P. (2006) Using Corpora in Discourse Analysis, London: Continuum.

BBC (2008) 'On This Day: 2001: Two Stabbed in Bradford Race Riots'. Available from:

http://news.bbc.co.uk/onthisday/hi/dates/stories/july/7/newsid 2496000/2496003.stm [accessed 28.01.13].

BBC (2012a) 'Census Shows Rise in Foreign-Born: Ethnicity in Graphics'. Available from: http://www.bbc.co.uk/news/uk-20687168 [accessed 26.01.13].

BBC (2012b) 'Census Shows Rise in Foreign-Born: At-a-Glance'. Available from: http://www.bbc.co.uk/news/uk-20677321 [accessed 26.01.13].

Bennett, C. (2011) 'Subdivisions of Islam', in Marshall Cavendish Corporation (ed.) Islamic Beliefs, Practices and Cultures, New York: Marshall Cavendish Reference (pp. 128-149).

Billig, M. (1991) Ideology and Opinions: Studies in Rhetorical Psychology, London: Sage.

Brians, P. (2004) 'Notes for Salman Rushdie: The Satanic Verses'. Available from: http://public.wsu.edu/ brians/anglophone/satanic verses/svnotes.pdf [accessed 25.01.13].

Elgamri, E. (2010) Islam in the British Broadsheets, Reading: Ithaca Press.

Featherstone, M., Holohan, S. and Poole, E. (2010) 'Discourses of the War on Terror: Constructions of the Islamic Other After 7/7', International Journal of Media and Cultural Politics, 6, 2, 169-186.

Fowler, R. (1991) Language in the News: Discourse and Ideology in the Press, London: Routledge.

Frost, D. (2008) 'Islamophobia: Examining Causal Links Between the Media and "Race Hate" from "Below"', International Journal of Sociology and Social Policy, 28, 11, 564-578.

Guardian (2001) 'Report Criticises Racial Divisions in Bradford'. Available from: http://www.guardian.co.uk/uk/2001/jul/12/race.world1 [accessed 28.01.13].

Hall, S. (1990) 'The Whites of their Eyes: Racist Ideologies and the Media', in M. Alvarado and J.O. Thompson (eds.) The Media Reader, London: British Film Institute (pp. 7-23). 
Herbert, I. (2001) 'How Rumours and Racists Sparked Britain's Worst Inner-City Rioting for Two Decades', Independent, 9 July, 3.

Hawkins, J.M. and Allen, R. (1991) The Oxford Encyclopaedic English Dictionary, Oxford: Oxford University Press.

Jakubowicz, A., Goodall, H., Martin, J., Mitchell, T., Randall, L. and Seneviratne, K. (1994) Racism, Ethnicity and the Media, Sydney: Allen and Unwin.

Kundnani, A. (2001) 'From Oldham to Bradford: The Violence of the Violated', Race and Class, 43, 2, 105-110).

Law, I. (2002) Race in the News, Basingstoke: Palgrave.

Law, I. (2010) Racism and Ethnicity: Global Debates, Dilemmas, Directions, Harlow: Longman/Pearson.

Mail on Sunday (2001) 'Two Are Stabbed as Anti-Racist Rally Erupts in Violence', Mail on Sunday, 8 July, 2.

Mautner, G. (2009) 'Checks and Balances: How Corpus Linguistics can Contribute to CDA', in R. Wodak and M. Meyer (eds.) Methods of Critical Discourse Analysis, London: Sage (pp. 122-143).

Moore, K., Mason, P. and Lewis, J. (2008) 'Images of Islam in the UK: The Representation of British Muslims in the National Print News Media 2000-2008'. Available from:

http://www.channel4.com/news/media/pdfs/Cardiff\%20Final\%20Report.pdf [accessed 29.01.13].

Moss, A. (2001) '80 Cops Injured in Race Riot Rampage; Police Pelted With Petrol Bombs as City Explodes', The People, 8 July, 11.

Ouseley, H. (2001) 'Community Pride Not Prejudice: Making Diversity Work in Bradford'. Available from: http://www.bradford2020.com/pride/report.pdf [accessed 28.01.13].

Peach, C. (2005) 'Britain's Muslim Population: an Overview', in T. Abbas (ed.) Muslim Britain: Communities Under Pressure, London: Zed Books (pp. 18-30).

Poole, E. (2002) Reporting Islam: Media Representations and British Muslims, London: I.B. Tauris.

Poynting, S. and Mason, V. (2007) 'The Resistible Rise of Islamophobia: Anti-Muslim Racism in the UK and Australia Before 11 September 2001', Journal of Sociology, $43,1,61-96$. 
Rex, J. (2005) 'An Afterword on the Situation of British Muslims in a World Context', in T. Abbas (ed.) Muslim Britain: Communities Under Pressure, London: Zed Books (pp. 235-243).

Richardson, J.E. (2004) (Mis)Representing Islam: The Racism and Rhetoric of British Broadsheet Newspapers, Amsterdam: John Benjamins.

Rushdie, S. (1989) The Satanic Verses, New York: Viking.

Said, E.W. (1978) Orientalism, London: Penguin.

Said, E.W. (1981) Covering Islam, London: Routledge and Kegan Paul.

Sardar, Z. (2002) 'The Excluded Minority: British Muslim Identity After 11 September', in P. Griffith and M. Leonard (eds.) Reclaiming Britishness: Living Together After 11 September and the Rise of the Right, London: Foreign Policy Centre.

Simple, P. (2001) ‘Race Relations', Daily Telegraph, 13 July, 31.

van Dijk, T.A. (2000) 'New(s) Racism: A Discourse Analytical Approach', in S. Cottle (ed.) Ethnic Minorities and the Media, Maidenhead: Open University Press (pp. 3349).

Ward, D. (2001) 'Nine Hours on the Bradford Frontline', Guardian, 11 July, 7.

\section{Biography}

Matt Atkinson is originally from Preston, Lancashire, and studied at the University of Liverpool. He is the author of a $\mathrm{PhD}$ thesis entitled "A Study of the Representation of 'Muslim' and 'Asian' Identities in the British National Press' (2012), and is currently working as a copywriter. He can be contacted at mattatkinson42@ hotmail.com. 